\title{
ANALISIS FAKTOR-FAKTOR YANG MEMPENGARUHI LOYALITAS KARYAWAN PADA PT. KARYA SWADAYA ABADI (KARSA) MEDAN
}

\author{
Betniar Purba \\ Universitas Katolik Santo Thomas Medan Jl. Setia Budi No. 479F, 20132, Indonesia \\ e-mail: betniarpurba20@gmail.com
}

\begin{abstract}
The purpose of this research is to know and analyze the most factors Dominant influence employee loyalty PT. Karya Swadaya Abadi (Karsa) Medan, The number of samples is 70 respondents. Types of data used primary and secondary data, and methods of data collection through questionnaires and documentation, data analysis methods used factor analysis. From the results of the study and discussion, the number of KMO Measure of Sampling Adeguacy (MSA) was 0.851 with a significance level of 0.000, because the value of KMO above 0.50 and significant at 1 percent, then the data is feasible enough to be analyzed further by using factor analysis. The scree plot shows the graph, where from factor 1 to factor 2 (source line component number =1, to 2), the direction of the line decreases quite sharply. Then from point 2 to 3 , the line still decreases with the smaller slope. The fourth factor is already below the number of Y axes (eigenvalues). This shows that the three best factors to summarize the fourteen factors affecting employee loyalty at PT. Karya Swadaya Abadi (Karsa) Medan. The dominant factors affect employee loyalty PT. The work of Swadaya Abadi (Karsa) Medan with a correlation value greater than 0.80 consists of: incentives (0.823), status (0.821), and promotion (0.813). As for suggestions given as consideration to the leadership of the company is to increase employee loyalty, should the company hire the best performing contract employees to permanent employees. Instead, the company maintains incentives to employees who excel to increase employee loyalty to the company.
\end{abstract}

Keywords: employee loyalty

\section{PENDAHULUAN}

Loyalitas karyawan menunjukkan suatu keinginan yang kuat untuk menjadi anggota organisasi, keinginan menuju level keahlian tinggi atas nama organisasi, suatu kepercayaan tertentu di dalam, dan penerimaan terhadap nilai-nilai dan tujuan organisasi tersebut.

Faktor-faktor yang mempengaruhi lovalitas karyawan adalah umur, masa kerja dalam organisasi, pembayaran gaji, desain kerja, gaya kepemimpinan, karakteristik pekerjaan, perlakuan organisasi terhadap karyawan, promosi jabatan, kemampuan, pelatihan, dan pemberian insentif bagi karyawan yang berprestasi terbaik. Apabila salah satu faktor ini berubah, maka loyalitas karyawan terhadap organisasi akan berubah.

Pramesti (2009) menjelaskan ada tiga faktor yang dapat mempengaruhi loyalitas karyawan terhadap perusahaan, yaitu (a). atribut-atribut personal (personal atributs), seperti usia individu, jenis kelamin, pendidikan, (b) faktor organisasional (organizational factors), seperti besar kecilnya organisasi dan sentralisasi otonomi, serta (c) faktor-faktor yang berkaitan dengan peran (role-related factor), seperti beban pekerjaan dan keterampilan bawahan.

I Ketut Andy Hermawan dan I Gede Riana (2012), menunjukkan bahwa Metode yang digunakan adalah Principal Component Analysis (PCA) dengan 20 variabel yang digunakan diperoleh 4(empat) faktor yang menentukan loyalitas karyawan dengan nilai sebesar 74, 45 $\%$ yang mampu menjelaskan semua varian yang ada dalam data. Adapun faktor-faktor yang mempengaruhi loyalitas karyawan pada PT. Inti Buana Permai Denpasar yaitu Faktor kompensasi nilai eigen value sebesar 4,366, faktor tanggung jawab memiliki eigen value sebesar 3, 925, faktor disiplin memiliki eigen value 3,862 dan faktor partisipasi nilai eigen value sebesar 2, 738. Variabel mewakili setiap faktor untuk menentukan loyalitas karyawan di PT Inti Buana 
Permai adalah variabel tunjangan tunjangan transportasi dengan loading factor 0,819, variabel kesuksesan dengan loading factor 0,873, variabel absensi dengan loading factor 0,855 dan variabel inisiatif dan kreatif dengan loading factor 0,780.

Selanjutnya hasil penelitian Rukmi Tien Martiwi dan Ahmad Mardalis (2012) menyatakan motivasi kerja, kompensasi, manajemen karir dan tekanan kerja berpengaruh positif dan signifikan terhadap loyalitas kerja.

PT. Karya Swadaya Abadi (Karsa) Medan merupakan salah satu perusahaan jasa transportasi. Diiketahui bahwa loyalitas karyawan menurun, hal ini terlihat dari gejala banyaknya karyawan yang pindah dan bekerja di perusahaan lain. Pada tahun 2013, pegawai yang pindah dan bekerja di perusahaan lain 6 orang, tahun 2014 meningkat menjadi 8 orang dan tahun 2015 juga mengalami peningkatan sebanyak 10 orang. Pada awal menerima karyawan baru, PT. Karya Swadaya Abadi (Karsa) Medan menetapkan status karyawan sebagai karyawan kontrak. Jika setelah dua tahun menunjukkan prestasi yang baik, yaitu supir mampu mencapai standar pendapatan per tahun Rp 54.000.000,00 (12 bulan x Rp 4.500.000,00/bulan), maka perusahaan mengangkatnya menjadi karyawan tetap perusahaan. Penetapan status sebagai karyawan tetap bertujuan untuk meningkatkan loyalitas karyawan terhadap perusahaan.

PT. Karya Swadaya Abadi (Karsa) Medan memberikan kesempatan bagi karyawan yang berprestasi terbaik untuk menduduki jabatan yang lebih tinggi. Dengan adanya promosi jabatan tersebut, perusahaan mengharapkan loyalitas karyawan terhadap organisasi semakin meningkat. Pada tahun 2012, karyawan bagian operasi (supir) yang mendapat kesempatan untuk dipromosikan menjadi kepala bagian operasi sebanyak 1 orang. Supir ini dipromosikan ke 1jabatan yang lebih tinggi karena selama 3 tahun berturut-turut, prestasi kerjanya melebihi standar pendapatan yang ditetapkan perusahaan. Pada tahun 2014, karyawan tersebut juga dipromosikan menjadi Pelaksana Harian Manager (PHM). Oleh karena itu, masalah yang akan diteliti yaitu untuk mengetahui Faktor apa yang paling dominan mempengaruhi loyalitas karyawan pada PT. Karya Swadaya Abadi (Karsa) Medan?"

\section{TINJAUAN PUSTAKA}

\section{A. Pengertian dan Komponen Loyalitas Karyawan}

Loyalitas karyawan adalah sikap seseorang terhadap organisasi dimana dia bekerja (Setiwati dan Zulkaida, 2007). Karyawan dengan loyalitas yang tinggi diindikasikan memiliki kebutuhan dan harapan yang tinggi terhadap organisasi tempatnya bekerja, serta lebih termotivasi saat harapannya terpenuhi. Januarti dan Bunyaanudin (2006:3), "loyalitas karyawan didefinisikan sebagai (1) sebuah kepercayaan dan penerimaan terhadap tujuantujuan dan nilai-nilai dari organisasi dan atau profesi, (2) sebuah kemauan untuk menggunakan usaha yang sungguh-sungguh guna kepentingan organisasi dan atau profesi, (3) sebuah keinginan untuk memelihara keanggotaan dalam organisasi dan atau profesi".

Menurut Meyer dan Smith dalam Spector (2000), ada tiga komponen loyalitas karyawan yaitu:

1. Loyalitas kerja afektif, yaitu loyalitas sebagai keterikatan afektif/psikologis karyawan terhadap pekerjaannya. Loyalitas ini menyebabkan karyawan bertahan terhadap suatu pekerjaan karena mereka menginginkannya.

2. Loyalitas kerja kontinue, mengarah pada perhitungan untung rugi pada diri karyawan sehubungan dengan keinginannya untuk tetap mempertahankan dan meninggalkan pekerjaannya. Artinya, loyalitas di sini dianggap sebagai persepsi harga yang harus dibayar jika karyawan meninggalkan pekerjaannya. Loyalitas ini menyebabkan karyawan bertahan pada suatu pekerjaan karena mereka membutuhkannya.

3. Loyalitas kerja normatif, yaitu loyalitas sebagai kewajiban untuk bertahan dalam pekerjaan Loyalitas ini menyebabkan karyawan bertahan pada suatu pekerjaan karena 
mereka merasa wajib melakukannya serta didasari pada adanya keyakinan tentang apa yang benar dan berkaitan dengan masalah moral.

Ketiga komponen di atas, hadir dalam diri karyawan dengan kadar yang berbedabeda, sehingga menghasilkan perilaku yang berbeda pula sebagai latar belakang dalam mempertahankan pekerjaan. Menurut Armansyah (2002:3), loyalitas organisasi sebagai kekuatan yang bersifat relatif dari individu dalam mengidentifikasikan keterlibatan dirinya ke dalam bagian organisasi. Hal ini dapat ditandai dengan tiga hal, yaitu:

a. Penerimaan terhadap nilai-nilai dan tujuan organisasi.

b. Kesiapan dan kesedian untuk berusaha dengan sungguh-sungguh atas nama organisasi.

c. Keinginan untuk mempertahankan keanggotaan di dalam organisasi (menjadi bagian dari organisasi).

\section{B. Membangun Loyalitas Karyawan}

Loyalitas karyawan terhadap organisasi merupakan sebuah proses berkesinambungan dan merupakan sebuah pengalaman individu ketika bergabung dalam sebuah organisasi. Menurut Djodiismanto (2007:2), ada empat cara meningkatkan loyalitas:

1. Perhatian khusus kepada karyawan khusus. Ini bisa diimplementasikan dengan cara menaikan jabatan dan meningkatkan gaji. Untuk mengetahui perkembangan karyawan, perusahaan harus memantau kerja karyawan. Karyawan berkualitas harus diberikan kompensasi positif, salah satunya bonus. Cara ini akan mengikat karyawan untuk enggan pindah kerja karena semua kebutuhan sudah dipenuhi perusahaan.

2. Membangun nilai kekeluargaan. Nilai ini bisa dibangun dengan cara makan siang bersama karyawan terpilih. Tidak perlu setiap hari, makan siang bersama bisa dilakukan dalam satu bulan atau minggu sekali. Dari sini akan terbangun keakraban antara karyawan dengan pemimpin. Dalam kondisi akan terlontar pembicara-pembicara non formal yang membuat suasana menjadi santai dan akrab.

3. Meningkatkan karier. Menaikan jabatan karyawan berprestasi sangat perlu dilakukan, karena itu merupakan satu kebanggaan. Karyawan paling senang bila mereka menduduki jabatan yang lebih tinggi. Ini merupakan satu prestasi kerja, dengan imbalan ini mereka akan meningkatkan semangat kerja. Jangan biarkan karyawan berprestasi pindah kerja, karena mereka adalah aset perusahaan yang nilainya tidak kalah dengan keuntungan.

4. Analisa. Dengan menganalisa keadaan karyawan pemimpin akan tahu kondisi dan tingkat kebutuhan karyawan. Setiap karyawan mempunyai tingkat kebutuhan berbedabeda. Dalam memenuhi kebutuhan karyawan tidak bisa disama ratakan, setiap karyawan mempunyai tingkat kebutuhan berbeda-beda. Tingkat kebutuhan karyawan berusia 22-25 tahun, di mana mereka baru lulus kuliah dan belum menikah berbeda dengan karyawan berusia 30-35 tahun. Karyawan berusia 22-25 tahun mempunyai sifat ingin belajar dan tingkat kebutuhan terhadap materi masih kecil. Karyawan pada level ini lebih cocok jika berikan learning center atau pendidikan tambahan. Pendidikan tambahan akan menjadi bekal pengembangan karier. Berbeda dengan karyawan berusia 30-35 tahun.

Menurut Sopiah (2008:159), cara yang bisa dilakukan untuk membangun loyalitas karyawan pada organisasi, adalah:

a. Make it charismatic (jadikan visi dan misi organisasi berkarismatik). Jadikan visi dan misi organisasi sebagai sesuatu yang karismatik, sesuatu yang dijadikan dasar bagi setiap karyawan dalam berperilaku, bersikap dan bertindak.

b. Build the tradition (segala sesuatu dijadikan tradisi). Segala sesuatu yang baik di organisasi jadikanlah sebagai suatu tradisi yang terus menerus dipelihara, dijaga oleh generasi berikutnya.

Analisis Faktor-Faktor Yang Mempengaruhi Loyalitas Karyawan Pada PT. Karya Swadaya 
c. Have comprehensive grievance procedure (memiliki prosedur untuk mengatasi keluhan secara menyeluruh). Bila ada keluhan atau komplain dari pihak luar ataupun dari internal organisasi maka organisasi harus memiliki prosedur untuk mengatasi keluhan tersebut secara menyeluruh.

d. Provide extensive two way communications (menjalin komunikasi dua arah). Jalinlah komunikasi dua arah tanpa memandang rendah bawahan.

e. Create a sense of community (semua unsur menjadi komunitas). Jadikan semua unsur dalam organisasi sebagai suatu komunitas di mana di dalamnya ada nilai-nilai kebersamaan, rasa memiliki, kerja sama dan berbagi.

f. Build value based homogenety (membangun nilai-nilai yang didasarkan adanya kesamaan). Setiap anggota organisasi memiliki kesempatan yang sama, misalnya untuk dipromosikan maka dasar yang digunakan untuk promosi adalah kemampuan, keterampilan, minat, motivasi, kinerja, dan tanpa diskriminasi.

g. Share and share alike (membuat kebijakan tanpa terkecuali). Sebaiknya organisasi membuat kebijakan di mana antara karyawan level bawah sampai yang paling atas tidak terlalu berbeda atau mencolok dalam kompensasi yang diterima, gaya hidup dan penampilan.

h. Emphasize barnraising, cross utilization and teamwork (membuat anggota organisasi saling bekerja sama dalam sebuah team kerja). Organisasi sebagai suatu komunitas harus bekerja sama, saling berbagi, saling memberi manfaat dan memberikan kesempatan yang sama pada anggota organisasi.

i. Get together (mengadakan acara bersama). Adakan acara-acara yang melibatkan semua anggota organisasi sehingga kebersamaan bisa terjalin. Misalnya, sekali-kali produksi dihentikan dan semua karyawan terlibat dalam acara rekreasi bersama keluarga, pertandingan olahraga, seni yang dilakukan oleh semua anggota organisasi dan keluarganya.

j. Support employee development (memperhatikan karir karyawan). Hasil studi menunjukkan bahwa karyawan lebih marasa memiliki organisasi bila diperhatikan perkembangan karier karyawan dalam jangka panjang.

k. Commit to actualizing (kesempatan untuk aktualisasi diri). Setiap karyawan diberi kesempatan yang sama untuk mengaktualisasikan diri secara maksimal di organisasi sesuai dengan kapasitas masing-masing.

1. Provide first year job challenge (mengembangkan potensi karyawan untuk mewujudkan impiannya). Karyawan masuk ke organisasi dengan membawa mimpi dan harapannya, kebutuhannya. Berikan bantuan yang kongkrit bagi karyawan untuk mengembangkan potensi yang dimilikinya dan mewujudkan impiannya. Jika pada tahap-tahap awal karyawan memiliki persepsi positif terhadap organisasi, maka karyawan akan cenderung memiliki kinerja yang tinggi pada tahap-tahap berikutnya.

m. Promote from within (mempromosikan dari dalam). Bila ada lowongan jabatan, sebaiknya kesempatan pertama diberikan kepada pihak intern perusahaan sebelum merekrut karyawan di luar perusahaan.

n. Provide development activities (menyediakan aktivitas pengembangan). Bila organisasi membuat kebijakan untuk merekrut karyawan dari dalam sebagai prioritas, maka dengan sendirinya hal itu akan memotivasi karyawan untuk terus tumbuh dan berkembang personalnya, juga jabatannya.

o. The question of employee securit (kenyamanan karyawan). Bila karyawan merasa aman, baik fisik maupun phisik, maka loyalitas akan muncul dengan sendirinya. Misalnya, karyawan merasa aman, karena perusahaan membuat kebijakan memberikan kesempatan karyawan bekerja selama usia produktif. Dia akan merasa aman dan tidak takut akan pemutusan hubungan kerja. Dia merasa aman karena keselamatan kerja diperhatikan perusahaan.

p. Commit to people first values (membangun nilai-nilai utama). Membangun loyalitas karyawan pada organisasi merupakan proses yang panjang dan tidak bisa dibentuk secara 
instan. Oleh karena itu, perusahaan harus benar-benar memberikan perlakuan yang benar pada masa awal karyawan memasuki organisasi.

q. Put in writing (strategi organisasi tertulis). Data-data tentang kebijakan, visi, misi, semboyan, filosofi, sejarah dan strategi organisasi sebaiknya dibuat dalam bentuk tulisan, bukan sekedar bahasan lisan.

r. Hire right kind managers (manager menjadi teladan). Bila pimpinan ingin menanamkan nilai-nilai, kebiasaan, aturan-aturan dan disiplin pada bawahan, sebaiknya pimpinan sendiri memberikan teladan dalam bentuk sikap dan perilaku sehari-hari.

s. Walk the talk (tindakan lebih efektif dari sekedar kata-kata). Bila pimpinan ingin karyawannya berbuat sesuatu, maka sebaiknya pimpinan mulai berbuat sesuatu, tidak sekedar kata-kata berbicara.

Banyak hal yang menyebabkan seorang karyawan tidak loyal pada perusahaan, diantaranya ketidaksanggupan perusahaan menjaga kenyamanan kerja dan tidak adanya transparansi. Hal-hal seperti kurang diperhatikan perusahaan karena dianggap tidak penting. Perlu disadari bahwa loyalitas mempunyai peranan penting dalam kemajuan perusahaan.

\section{Faktor-faktor yang Mempengaruhi Loyalitas Karyawan}

Menurut Setiwati dan Zulkaida (2007), faktor-faktor yang mempengaruhi loyalitas karyawan terhadap pekerjaan adalah:

1. Karakteristik pekerjaan

2. Kesempatan adanya pekerjaan lain

3. Karakteristik individu

4. Perlakuan organisasi terhadap karyawan

Karyawan yang merasa puas memiliki loyalitas yang tinggi terhadap organisasi. Rendahnya kepuasan kerja ini mendorong karyawan untuk tidak komit kepada organisasi, sehingga merugikan organisasi itu sendiri seperti menurunnya prestasi kerja, rendahnya semangat kerja, menurunnya tingkat disiplin.

Faktor-faktor pembentuk loyalitas organisasional akan berbeda bagi karyawan yang baru bekerja, setelah menjalani masa kerja yang cukup lama, serta bagi karyawan yang bekerja dalam tahapan yang lama menganggap perusahaan atau organisasi tersebut sudah menjadi bagian dalam hidupnya.

Menurut Sopiah (2008:163), faktor-faktor yang mempengaruhi loyalitas karyawan adalah:

a. Faktor personal, misalnya usia, jenis kelamin, tingkat pendidikan, pengalaman kerja, dan kepribadian.

b. Karakteristik pekerjaan, misalnya lingkup jabatan, tantangan dalam pekerjaan, konflik peran dalam pekerjaan, dan tingkat kesulitan dalam pekerjaan.

c. Karakteristik struktur, misalnya besar kecilnya organisasi, bentuk organisasi, seperti sentralisasi atau desentralisasi, kehadiran serikat pekerja dan tingkat pengendalian yang dilkaukan organisasi terhadap karyawan.

d. Pengalaman kerja. Pengalaman kerja karyawan sangat berpengaruh terhadap tingkat loyalitas karyawan pada organisasi. Karyawan yang baru beberapa tahun bekerja dan karyawan yang sudah puluhan tahun bekerja dalam organisasi tentu memiliki tingkat loyalitas yang berlainan. 


\section{METODE PENELITIAN}

\section{A. Populasi dan Sampel}

Populasi pada penelitian ini adalah seluruh karyawan PT. Karya Swadaya Abadi (Karsa) Medan sebanyak 102 orang dengan perincian sebagai berikut:

Tabel 1. Sampel Penelitian

\begin{tabular}{|c|l|c|c|}
\hline No. & \multicolumn{1}{|c|}{ Bagian } & Populasi (orang) & Sampel (orang) \\
\hline 1 & Operator & 7 & $7: 102 \times 70=5$ \\
\hline 2 & Pengawas lapangan & 12 & $12: 102 \times 70=8$ \\
\hline 3 & Bagian teknik & 20 & $20: 102 \times 70=15$ \\
\hline 4 & Bagian operasi & 56 & $56: 102 \times 70=38$ \\
\hline 5 & Bagian pembayaran & 7 & $7: 102 \times 70=5$ \\
\hline \multicolumn{2}{|c}{ Jumlah } & 102 & 70 \\
\hline
\end{tabular}

Menurut Hair dkk., (2000:365), "jumlah sampel dalam analisis faktor adalah 5 x n". Penelitian ini menggunakan 14 variabel (n), maka sampel penelitian adalah $5 \times 14=70$ orang. Teknik penentuan sampel adalah stratified random sampling, yaitu sampel diambil secara acak dari masing-masing bagian.

\section{B. Operasionalisasi Variabel}

Definisi operasionalisasi variabel yang diteliti adalah:

1. Umur, yaitu umur karyawan yang ikut terlibat dan bekerja pada PT. Karya Swadaya Abadi (Karsa) Medan.

2. Masa kerja, yaitu lamanya karyawan bekerja pada PT. Karya Swadaya Abadi (Karsa) Medan.

3. Pembayaran gaji, yaitu ketepatan waktu pembayaran gaji yang dilakukan setiap awal bulan.

4. Desain kerja, yaitu pembagian tugas, tanggungjawab dan wewenang masing-masing bagian sesuai keahlian dan keterampilannya.

5. Gaya kepemimpinan, yaitu kemampuan atasan untuk memimpin dan mempengaruhi bawahan agar mau melakukan suatu pekerjaan tertentu.

6. Promosi jabatan, yaitu pemindahan karyawan dari suatu jabatan ke jabatan lain yang mempunyai status atau tingkatan manajemen dan tanggungjawab yang lebih tinggi.

7. Karakteristik pekerjaan, yaitu kondisi pekerjaan dimana karyawan ditempatkan.

8. Perlakuan organisasi terhadap karyawan, yaitu perusahaan memperlakukan karyawan dengan baik melalui pemberian balas jasa layak

9. Kemampuan, yaitu penempatan tenaga kerja disesuaikan dengan kemampuan yang dimiliki oleh masing-masing karyawan.

10. Pelatihan, yaitu karyawan selalu diberikan pelatihan untuk meningkatkan kemampuan dan keterampilannya.

11. Keterlibatan karyawan, yaitu atasan melibatkan bawahan dalam mengambil keputusan.

12. Insentif, yaitu perusahaan memberikan insentif kepada karyawan yang bekerja di luar jam kerja normal dan bagi para supir diberikan insentif jika sewa penumpang yang diperoleh melebihi standar yang ditetapkan.

13. Status, yaitu perusahaan menetapkan status karyawan sebagai karyawan tetap.

14. Kebijakan organisasi, yaitu perusahaan menetapkan kebijakan yang mengatur tugas, tanggungjawab dan wewenang kepada masing-masing karyawan.

Skala pengukurannya variabel penelitian adalah skala likert. 


\section{Volume 17 Nomor 1}

\section{Teknik Pengumpulan Data}

Pada penelitian ini digunakan data primer melalui kuesioner dan wawancara

\section{Metode Analisis}

\section{D.1. Uji Validitas dan Reliabilitas instrumen}

Pengujian validitas tiap butir digunakan analisis item dengan rumus:

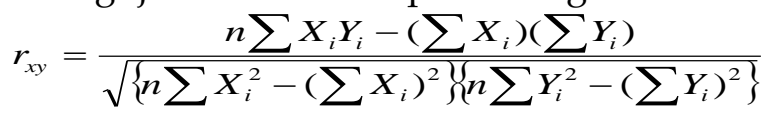

Keterangan: $X_{i}=$ Skor tiap butir indikator, $Y_{i}=$ Skor total butir

$$
\mathrm{n}=\text { Jumlah sampel }
$$

Pengujian reabilitas instrumen dilakukan dengan teknik belah dua dari Spearmen Brown dengan rumus :

$$
r i=\frac{2 r b}{1+r b}
$$

Keterangan $: r_{i}=$ reliabitas internal seluruh instrumen

$\mathrm{rb}=$ korelasi product moment antara belahan pertama dan kedua

Perhitungan reliabilitas menggunakan Cronbach Alpha dengan kriteria pengujian sebagai berikut:

$a \geq 0,5$ artinya instrumen reliabel.

$a<0,5$ artinya instrumen tidak reliabel.

\section{D.2. Analisis Faktor}

Model dasar analisis faktor adalah data hasil observasi dari beberapa faktor $\left(f_{n}\right)$. Secara matematis persamaan ini menjadi (Arikunto, 2002: 165):

$$
X i n=\lambda l f 1+\lambda 2 f 2 \neq \ldots . .+\lambda n f n+e i n
$$

Keterangan: $X_{\text {in }}=$ Nilai dari variabel ke-i untuk observasi ke-n

$\mathrm{f}_{1}=$ Faktor-faktor yang mempengaruhi loyalitas karyawan

$\lambda_{\mathrm{i}}=$ Hubungan antar variabel

$\lambda_{\text {ij }}$ yang biasa disebut factor loading, menunjukkan keterkaitan faktor dengan variabel yang diukur.. Jika nilai KMO (Kaiser Meyer Olkin) Measure of Sampling Adeguarcy (MSA) lebih besar 0,50, maka kumpulan variabel tersebut dapat diproses lebih lanjut.

Berdasarkan pengolahan data dilakukan dengan menggunakan program SPSS (Statistical Program for Social Sciences) versi 19.00. Hasil uji secara simultan disajikan pada tabel berikut ini:

Tabel 2. Case Processing Summary

\begin{tabular}{|ll|r|r|}
\hline & \multicolumn{1}{|c|}{$\mathrm{N}$} & \multicolumn{1}{c|}{$\%$} \\
\hline Cases & Valid & 30 & 100.0 \\
& Excluded (a) & 0 & .0 \\
& Total & 30 & 100.0 \\
\hline
\end{tabular}

a Listwise deletion based on all variables in the procedure

Berdasarkan tabel di atas, diketahui bahwa dari 30 jawaban responden $100 \%$ sudah valid. Hasill uji realiabilitas secara simultan disajikan pada tabel berikut:

Tabel 3. Reliability Statistics

\begin{tabular}{|c|c|}
\hline Cronbach's Alpha & N of Items \\
\hline 0,936 & 14 \\
\hline
\end{tabular}

Sumber: Hasil pengolahan data SPSS versi 19

Dari tabel di atas, terlihat bahwa keempat belas indikator pengukuran seluruhnya sudah 
Volume 17 Nomor 1

reliabel, karena Cronbach's Alpha $=0,936>0,50$.

\section{HASIL DAN PEMBAHASAN}

\section{KMO and Bartlett's Test}

Dari hasil output SPSS versi 19,00 untuk 14 variabel yang dijawab oleh 70 responden, ternyata didapat hasil sebagai berikut

Tabel 4. KMO and Bartlett's Test

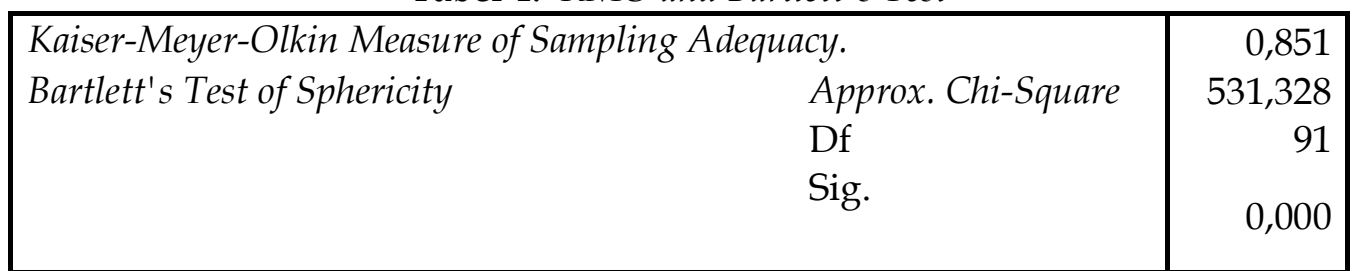

Sumber: Hasil pengolahan data SPSS versi 19

Dari tabel di atas, terlihat angka KMO (Kaiser-Meyer-Olkin) Measure of Sampling Adeguacy (MSA) adalah 0,851 di atas 0,50, dengan tingkat signifikansi 0,000, maka data cukup layak dianalisis lebih lanjut dengan menggunakan analisis faktor.

\section{Anti image Correction}

Anti image correlation menunjukkan variabel mana yang dapat diproses lebih lanjut dan mana yang harus dikeluarkan sebagai indikator penelitian. Hasil anti image correlation dan anti image covariance disajikan pada tabel berikut:

Tabel 5. Anti Image Matrices

\begin{tabular}{|rr|r|r|r|r|r|}
\hline & & \multicolumn{1}{|c|}{ V1 } & \multicolumn{1}{c|}{ V2 } & \multicolumn{1}{c|}{ V3 } & \multicolumn{1}{c|}{ V5 } \\
\hline Anti-image & V1 & 0,481 & 0,061 & $-0,040$ & $-0,083$ & $-0,052$ \\
& V2 & 0,061 & 0,533 & 0,043 & 0,032 & $-0,027$ \\
& V3 & $-0,040$ & 0,043 & 0,404 & $-0,005$ & $-0,124$ \\
& V4 & $-0,083$ & 0,032 & $-0,005$ & 0,358 & $-0,011$ \\
& V5 & $-0,052$ & $-0,027$ & $-0,124$ & $-0,011$ & 0,331 \\
& V6 & $-0,055$ & 0,037 & $-0,068$ & $-0,069$ & 0,073 \\
& V7 & $-0,016$ & $-0,058$ & $-0,038$ & 0,005 & $-0,037$ \\
& V8 & 0,040 & $-0,087$ & 0,022 & $-0,155$ & $-0,095$ \\
& V9 & $-0,045$ & $-0,078$ & 0,074 & $-0,077$ & $-0,165$ \\
& V10 & $-0,067$ & $-0,109$ & $-0,026$ & $-0,037$ & $-0,010$ \\
& V11 & $-0,036$ & $-0,009$ & $-0,022$ & $-0,056$ & $-0,008$ \\
& V12 & 0,024 & $-0,186$ & $-0,138$ & $-0,078$ & 0,042 \\
& V13 & $-0,016$ & $-0,061$ & $-0,050$ & 0,046 & $-0,011$ \\
& V14 & $-0,018$ & 0,037 & $-0,031$ & 0,047 & 0,017 \\
V1 & $0,950(\mathrm{a})$ & 0,121 & $-0,091$ & $-0,201$ & $-0,130$ \\
Anti-image & 0,121 & $0,852(\mathrm{a})$ & 0,093 & 0,073 & $-0,065$ \\
Correlation & V2 & $-0,091$ & 0,093 & $0,904(\mathrm{a})$ & $-0,012$ & $-0,339$ \\
& V3 & $-0,201$ & $-0,073$ & $-0,012$ & $0,888(\mathrm{a})$ & $-0,031$ \\
& V4 & $-0,130$ & $-0,065$ & $-0,339$ & $-0,031$ & $0,869(\mathrm{a})$ \\
& V5 & $-0,126$ & 0,080 & $-0,171$ & $-0,181$ & 0,201 \\
V6 & $-0,037$ & $-0,124$ & $-0,095$ & 0,012 & $-0,100$ \\
& V7 & $-0,192$ & 0,055 & $-0,418$ & $-0,265$ \\
V8 & $-0,092$ & $-0,178$ & 0,192 & $-0,212$ & $-0,475$ \\
V9 & $-0,107$ & $-0,059$ & $-0,090$ & $-0,024$ \\
V10 & $-0,139$ & $-0,216$ & $-0,023$ \\
\hline V11 & $-0,089$ & $-0,021$ & $-0,060$ & $-0,161$ & $-0,023$ \\
\hline
\end{tabular}




\begin{tabular}{|r|r|r|r|r|r|}
\hline & \multicolumn{1}{|c|}{ V1 } & \multicolumn{1}{|c|}{ V2 } & \multicolumn{1}{c|}{ V3 } & \multicolumn{1}{c|}{ V4 } & \multicolumn{1}{c|}{ V5 } \\
\hline V12 & 0,049 & $-0,361$ & $-0,308$ & $-0,185$ & 0,104 \\
V13 & $-0,036$ & $-0,134$ & $-0,127$ & 0,123 & $-0,031$ \\
V14 & $-0,047$ & 0,093 & $-0,091$ & 0,146 & 0,053 \\
\hline
\end{tabular}

Sumber: hasil pengolahan SPSS versi 19

\section{Pembahasan}

\section{Communalities}

Tabel 6. Communalities

\begin{tabular}{|l|c|c|}
\hline \multicolumn{1}{|c|}{$\begin{array}{c}\text { Faktor-faktor yang mempengaruhi loyalitas } \\
\text { karyawan }\end{array}$} & Initial & Extraction \\
\hline Umur $\left(\mathrm{V}_{1}\right)$ & 1,000 & 0,622 \\
Masa kerja $\left(\mathrm{V}_{2}\right)$ & 1,000 & 0,672 \\
Pembayaran gaji $\left(\mathrm{V}_{3}\right)$ & 1,000 & 0,617 \\
Desain kerja $\left(\mathrm{V}_{4}\right)$ & 1,000 & 0,675 \\
Gaya kepemimpinan $\left(\mathrm{V}_{5}\right)$ & 1,000 & 0,651 \\
Promosi jabatan $\left(\mathrm{V}_{6}\right)$ & 1,000 & 0,698 \\
Karakteristik pekerjaan $\left(\mathrm{V}_{7}\right)$ & 1,000 & 0,614 \\
Perlakuan organisasi $\left(\mathrm{V}_{8}\right)$ & 1,000 & 0,583 \\
Kemampuan $\left(\mathrm{V}_{9}\right)$ & 1,000 & 0,561 \\
Pelatihan $\left(\mathrm{V}_{10}\right)$ & 1,000 & 0,517 \\
Keterlibatan karyawan $\left(\mathrm{V}_{11}\right)$ & 1,000 & 0,685 \\
Insentif $\left(\mathrm{V}_{12}\right)$ & 1,000 & 0,734 \\
Status $\left(\mathrm{V}_{13}\right)$ & 1,000 & 0,735 \\
Kebijakan organisasi $\left(\mathrm{V}_{14}\right)$ & 1,000 & 0,764 \\
\hline
\end{tabular}

Extraction Method: Principal Component Analysis

\section{Total Variance Explained}

Ada 14 variabel yang dimasukkan dalam analisis faktor, dengan masing-masing variabel mempunyai varians 1 , maka total varians adalah $14 \times 1=14$. Jika 14 variabel tersebut diringkas menjadi satu faktor, maka varians yang dapat dijelaskan oleh satu faktor tersebut adalah:
a. Varians faktor pertama adalah
$6,788: 14 \times 100 \%=48,412 \%$
b. Varians faktor kedua adalah
$1,260: 14 \times 100 \%=9,000 \%$.
c. Varians faktor ketiga adalah
$1,090: 14 \times 100 \%=7,787 \%$.

Total ketiga faktor tersebut adalah 65,199\%, yang berarti bahwa ketiga faktor tersebut dapat menjelaskan 65,199\% dari variabilitas 14 variabel tersebut. Eigenvalues menunjukkan kepentingan relatif masing-masing faktor dalam menghitung varians 14 variabel yang dianalisis.

Jumlah angka eigenvalues untuk 14 variabel adalah $\{6,778+1,260+1,090+0,947+0,729+$ $0,578+0,535+0,495+0,427+0,335+0,254+0,240+0,183+0,148\}=14$. Susunan eigenvalues selalu diurutkan dari yang terbesar sampai terkecil, dengan kriteria bahwa angka eigenvalues di bawah 1 tidak digunakan dalam menghitung jumlah faktor yang terbentuk. Scree plot disajikan pada Gambar berikut: 


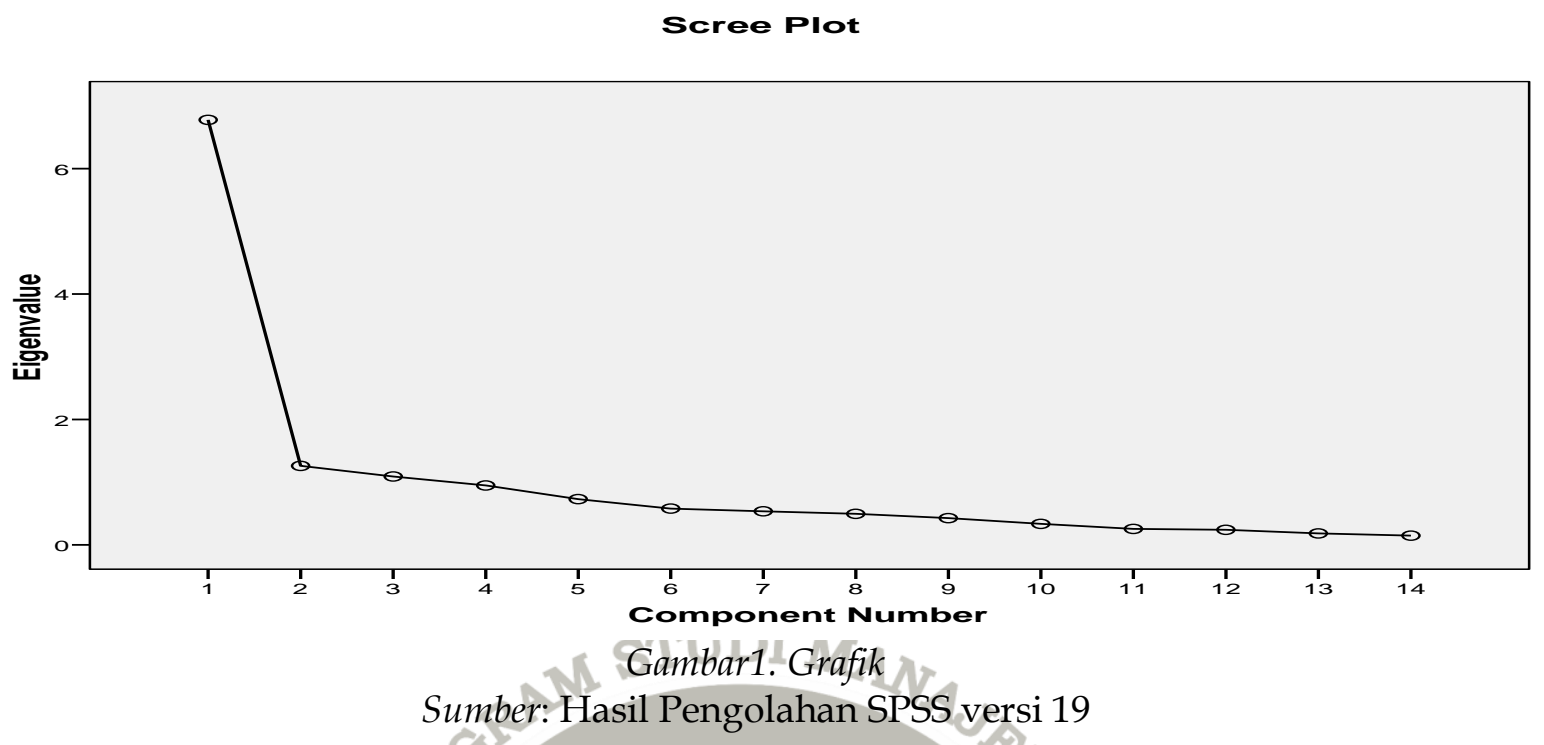

Component Matrix

Tabel 7. Component Matrix

\begin{tabular}{|l|r|r|r|}
\hline \multicolumn{1}{|c|}{$\begin{array}{c}\text { Faktor-faktor yang mempengaruhi } \\
\text { loyalitas karyawan }\end{array}$} & $\mathbf{1}$ & \multicolumn{1}{c|}{ Component } \\
\cline { 2 - 4 } & 0,723 & $-0,225$ & \multicolumn{1}{c|}{$\mathbf{3}$} \\
\hline Umur $\left(\mathrm{V}_{1}\right)$ & 0,584 & 0,388 & 0,425 \\
Masa kerja $\left(\mathrm{V}_{2}\right)$ & 0,761 & 0,175 & $-0,087$ \\
Pembayaran gaji $\left(\mathrm{V}_{3}\right)$ & 0,761 & $-0,292$ & $-0,103$ \\
Desain kerja $\left(\mathrm{V}_{4}\right)$ & 0,776 & $-0,151$ & 0,162 \\
Gaya kepemimpinan $\left(\mathrm{V}_{5}\right)$ & 0,690 & $-0,238$ & $-0,406$ \\
Promosi jabatan $\left(\mathrm{V}_{6}\right)$ & 0,639 & 0,427 & 0,154 \\
Karakteristik pekerjaan $\left(\mathrm{V}_{7}\right)$ & 0,646 & $-0,321$ & 0,250 \\
Perlakuan organisasi $\left(\mathrm{V}_{8}\right)$ & 0,709 & $-0,193$ & $-0,144$ \\
Kemampuan $\left(\mathrm{V}_{9}\right)$ & 0,681 & 0,225 & 0,046 \\
Pelatihan $\left(\mathrm{V}_{10}\right)$ & 0,794 & $-0,198$ & 0,123 \\
Keterlibatan karyawan $\left(\mathrm{V}_{11}\right)$ & 0,546 & 0,624 & $-0,215$ \\
Insentif $\left(\mathrm{V}_{12}\right)$ & 0,634 & $-0,157$ & 0,555 \\
Status $\left(\mathrm{V}_{13}\right)$ & 0,744 & 0,190 & $-0,417$ \\
Kebijakan organisasi $\left(\mathrm{V}_{14}\right)$ & &
\end{tabular}

Extraction Method: Principal Component Analysis a 3 components extracted

\section{Rotated Component Matrix}

Rotated component matrix berguna untuk memperjelas variabel-variabel mana yang masuk ke dalam tiap-tiap faktor.

Tabel 8. Rotated component matrix

\begin{tabular}{|l|r|r|c|}
\hline \multicolumn{1}{|c|}{$\begin{array}{c}\text { Faktor-faktor yang mempengaruhi } \\
\text { loyalitas karyawan }\end{array}$} & \multicolumn{3}{c|}{ Component } \\
\cline { 2 - 4 } Umur $\left(\mathrm{V}_{1}\right)$ & $\mathbf{0 , 7 1 9}$ & 0,189 & $\mathbf{2}$ \\
Masa kerja $\left(\mathrm{V}_{2}\right)$ & $-0,023$ & $\mathbf{0 , 6 2 2}$ & 0,533 \\
Pembayaran gaji $\left(\mathrm{V}_{3}\right)$ & 0,493 & $\mathbf{0 , 5 4 6}$ & 0,274 \\
Desain kerja $\left(\mathrm{V}_{4}\right)$ & $\mathbf{0 , 7 0 5}$ & 0,147 & 0,396 \\
Gaya kepemimpinan $\left(\mathrm{V}_{5}\right)$ & 0,496 & 0,268 & $\mathbf{0 , 5 7 7}$ \\
Promosi jabatan $\left(\mathrm{V}_{6}\right)$ & $\mathbf{0 , 8 1 3}$ & 0,165 & 0,101 \\
Karakteristik pekerjaan $\left(\mathrm{V}_{7}\right)$ & $\mathbf{0 , 1 5 9}$ & $\mathbf{0 , 6 9 2}$ & 0,332 \\
\hline
\end{tabular}




\begin{tabular}{|l|r|r|r|}
\hline \multicolumn{1}{|c|}{ Faktor-faktor yang mempengaruhi } & \multicolumn{3}{c|}{ Component } \\
\cline { 2 - 4 } loyalitas karyawan & $\mathbf{1}$ & $\mathbf{2}$ & \multicolumn{1}{c|}{$\mathbf{3}$} \\
\hline Perlakuan organisasi $\left(\mathrm{V}_{8}\right)$ & 0,430 & 0,053 & $\mathbf{0 , 6 2 9}$ \\
Kemampuan $\left(\mathrm{V}_{9}\right)$ & $\mathbf{0 , 6 5 1}$ & 0,206 & 0,308 \\
Pelatihan $\left(\mathrm{V}_{10}\right)$ & 0,339 & $\mathbf{0 , 5 4 4}$ & 0,325 \\
Keterlibatan karyawan $\left(\mathrm{V}_{11}\right)$ & 0,552 & 0,239 & $\mathbf{0 , 5 6 9}$ \\
Insentif $\left(\mathrm{V}_{12}\right)$ & 0,230 & $\mathbf{0 , 8 2 3}$ & $-0,069$ \\
Status $\left(\mathrm{V}_{13}\right)$ & 0,170 & 0,179 & $\mathbf{0 , 8 2 1}$ \\
Kebijakan organisasi $\left(\mathrm{V}_{14}\right)$ & $\mathbf{0 , 6 7 1}$ & 0,559 & $-0,004$ \\
\hline
\end{tabular}

Extraction Method: Principal Component Analysis. Rotation Method: Varimax with Kaiser Normalization. a Rotation converged in 7 iterations.

Tabel 9. Faktor-faktor Yang Mempengaruhi Loyalitas Karyawan PT. Karya Swadaya Abadi (Karsa) Medan

\begin{tabular}{|c|c|c|l|l|}
\hline Atribut & Korelasi & Faktor & \multicolumn{1}{c|}{ Keterangan } & \multicolumn{1}{|c|}{ Nama faktor } \\
\hline $\mathrm{V}_{6}$ & 0,813 & 1 & Promosi jabatan & Dukungan organisasi \\
$\mathrm{V}_{1}$ & 0,719 & 1 & Umur & \\
$\mathrm{V}_{4}$ & 0,705 & 1 & Desain kerja & \\
$\mathrm{V}_{14}$ & 0,671 & 1 & Kebijakan organisasi & \\
$\mathrm{V}_{9}$ & 0,651 & 1 & Kemampuan & Motivasi \\
\hline $\mathrm{V}_{12}$ & 0,823 & 2 & Insentif & dan \\
$\mathrm{V}_{7}$ & 0,692 & 2 & Karakteristik pekerjaan & pengembangan \\
$\mathrm{V}_{2}$ & 0,622 & 2 & Masa kerja & \\
$\mathrm{V}_{3}$ & 0,546 & 2 & Pembayaran gaji & \\
$\mathrm{V}_{10}$ & 0,544 & 2 & Pelatihan & \\
\hline $\mathrm{V}_{13}$ & 0,821 & 3 & Status & Dukungan manajemen \\
$\mathrm{V}_{8}$ & 0,629 & 3 & Perlakuan organisasi & \\
$\mathrm{V}_{5}$ & 0,577 & 3 & Gaya kepemimpinan & \\
$\mathrm{V}_{11}$ & 0,569 & 3 & Keterlibatan karyawan & \\
\hline
\end{tabular}

Sumber: diolah dari Tabel 6

Tabel 10. Component Transformation Matrix

\begin{tabular}{|c|r|r|r|}
\hline Component & $\mathbf{1}$ & $\mathbf{2}$ & $\mathbf{3}$ \\
\hline 1 & 0,680 & 0,518 & 0,519 \\
2 & $-0,431$ & 0,855 & $-0,288$ \\
3 & $-0,593$ & $-0,028$ & 0,804 \\
\hline
\end{tabular}

Extraction Method: Principal Component Analysis. Rotation Method: Varimax with Kaiser Normalization.

Dari Tabel di atas diketahui bahwa pada diagonal faktor (component) 1 yang berada di atas angka $0,50(0,6800,518$ dan 0,804$)$. Hal ini yang menunjukkan tiga faktor (component) yang terbentuk sudah tepat, karena mempunyai korelasi tinggi. Dengan demikian, antara faktor cenderung terjadi interkorelasi.

\section{Nilai Korelasi Setelah Rotasi}

Setelah dilakukan rotasi, diketahui korelasi antara faktor 1, faktor 2 dan faktor 3 terhadap loyalitas karyawan pada PT. Karya Swadaya Abadi (Karsa) Medan, yaitu nilai korelasi faktor pertama sebesar $26,771 \%$, faktor kedua sebesar $19,580 \%$ dan nilai faktor ketiga sebesar 18,848\%. Jumlah variansnya sebesar 65,199\%, hal ini menunjukkan masih terdapat faktor lain sebagai faktor yang mempengaruhi loyalitas karyawan yang belum terungkap 
sebesar 34,801\%. Dengan demikian, kedua belas faktor tersebut dapat menjelaskan loyalitas karyawan sebesar $65,199 \%$.

\section{Faktor yang Dominan Mempengaruhi Loyalitas Karyawan}

Faktor yang dominan mempengaruhi loyalitas karyawan PT. Karya Swadaya Abadi (Karsa) Medan dengan nilai korelasi lebih besar dari 0,80 terdiri dari: insentif $(0,823)$, status $(0,821)$, dan promosi jabatan $(0,813)$. Dilihat dari nilai korelasinya, diketahui bahwa faktor yang paling dominan mempengaruhi loyalitas karyawan adalah insentif.

PT. Karya Swadaya Abadi (Karsa) Medan meningkatkan loyalitas karyawan melalui pemberikan insentif kepada karyawan (supir) yang berprestasi melebihi standar pendapatan yang ditetapkan. Standar prestasi kerja yang diukur dari pendapatan sewa penumpang per hari sebesar Rp 180.000,00 dan hari kerja sebulan selama 25 hari, maka standar prestasi kerja (pendapatan) per bulan adalah :

Standar prestasi kerja $=25$ hari kerja $\times \operatorname{Rp~180.000,00/hari~}$

$$
=\operatorname{Rp} 4.500 .000,00 \text {. }
$$

Pada saat supir mencapai standar pendapatan sebesar Rp 4.500.000,00 per bulan, maka perusahaan memberikan insentif sebesar Rp 150.000,00. Akan tetapi, jika supir tidak mampu mencapai standar pendapatan yang diperoleh dari sewa penumpang, maka karyawan tersebut tidak mendapatkan insentif dari perusahaan. Pemberian insentif ini bertujuan untuk meningkatkan loyalitas dan semangat kerja para karyawan.

Bagi karyawan kantor, insentif diberikan pada saat karyawan bekerja melebihi standar jam kerja per hari selama 8 jam. Besar insentif yang diberikan perusahan sebesar Rp 5.250,00/jam. Misalnya, jika karyawan bagian kantor bekerja selama 10 jam untuk menyelesaikan tugas-tugasnya, maka insentif yang diberikan adalah standar jam kerja per hari dikurang total jam kerja dikali tarif upah insentif per hari. Dari informasi tersebut dapat dihitung insentif yang diterima karyawan kantor sebagai berikut:

Insentif karyawan kantor $=2$ jam $\times \operatorname{Rp} 5.250,00 /$ jam $=\operatorname{Rp} 10.500,00$.

Pada awal menerima karyawan baru, PT. Karya Swadaya Abadi (Karsa) Medan menetapkan status karyawan sebagai karyawan kontrak. Jika setelah dua tahun menunjukkan prestasi yang baik, yaitu supir mampu mencapai standar pendapatan per tahun Rp 54.000.000,00 (12 bulan $\times$ Rp 4.500.000,00/bulan), maka perusahaan mengangkatnya menjadi karyawan tetap perusahaan. Penetapan status sebagai karyawan tetap bertujuan untuk meningkatkan loyalitas karyawan terhadap perusahaan.

PT. Karya Swadaya Abadi (Karsa) Medan memberikan kesempatan bagi karyawan yang berprestasi terbaik untuk menduduki jabatan yang lebih tinggi. Dengan adanya promosi jabatan tersebut, perusahaan mengharapkan loyalitas karyawan terhadap organisasi semakin meningkat. Pada tahun 2014, karyawan bagian operasi (supir) yang mendapat kesempatan untuk dipromosikan menjadi kepala bagian operasi sebanyak 1 orang. Supir ini dipromosikan ke jabatan yang lebih tinggi karena selama 3 tahun berturut-turut, prestasi kerjanya melebihi standar pendapatan yang ditetapkan perusahaan. Pada tahun 2015, karyawan tersebut juga dipromosikan menjadi Pelaksana Harian Manager (PHM).

\section{KESIMPULAN DAN SARAN}

Kesimpulan

Berdasarkan hasil pembahasan yang telah dilakukan dapat disimpulkan bahwa:

1. Angka KMO (Kaser-Meyer-Olkin) Measure of Sampling Adeguacy (MSA) adalah 0,851 dengan tingkat signifikansi 0,000. Oleh karena nilai KMO di atas 0,50 dan signifikan pada 1 persen, maka data cukup layak untuk dianalisis lebih lanjut dengan menggunakan analisis faktor. 
2. Component Matrix menunjukkan bahwa variabel yang dianlisis belum jelas termasuk ke dalam faktor mana. Setelah dilakukan rotated component matrix, maka keempatbelas variabel yang diteliti sudah jelas dalam faktor 1, faktor 2 dan faktor 3 .

3. Scree plot menampakkan grafik, di mana dari faktor 1 ke faktor 2 (garis sumber component number $=1$ ke 2 ), arah garis menurun dengan cukup tajam. Kemudian dari angka 2 sampai angka 3, garis masih menurun dengan slope yang semakin kecil. Faktor keempat sudah berada di bawah angka dari sumbu Y (eigenvalues). Hal ini menunjukkan bahwa tiga faktor paling bagus untuk meringkas keempat belas faktor yang mempengaruhi loyalitas karyawan pada PT. Karya Swadaya Abadi (Karsa) Medan.

4. Faktor yang dominan mempengaruhi loyalitas karyawan PT. Karya Swadaya Abadi (Karsa) Medan dengan nilai korelasi lebih besar dari 0,80 terdiri dari: insentif $(0,823)$, status $(0,821)$, dan promosi jabatan $(0,813)$.

Saran

Saran yang diberikan sebagai bahan pertimbangan kepada pimpinan perusahaan adalah:

1. Untuk meningkatkan loyalitas karyawan, sebaiknya perusahaan mengangkat karyawan kontrak yang berprestasi terbaik menjadi karyawan tetap.

2. Sebaiknya, perusahaan mempertahankan pemberian insentif kepada karyawan yang berprestasi untuk meningkatkan loyalitas karyawan terhadap perusahaan.

\section{DAFTAR PUSTAKA}

Armansyah, 2002. Loyalitas Karyawan dan Imbalan Finansial, Jurnal Ilmiah "Manajemen \& Bisnis" Program Studi Manajemen, Fakultas Ekonomi Universitas Muhammadiyah Sumatera Utara

Arikunto, Suharsimi, 2002. Prosedur Penelitian: Suatu Pendekatan Praktek, Edisi Kelima, Jakarta : Rineka Cipta.

Djodiismanto, 2007. Cara Meningkatkan Loyalitas Karyawan, http://djodiismanto. blogspot.com.

Hair, Joseph F. Jr., Rolph E. Anderson, Ronald L. Tatham, \& William C. Black. 2000, Multivariate Data Analysis With Readings. Fourth Edition. New Jersey: Prentice-Hall, Inc.

Hasibuan, Malayu, 2003. Manajemen Sumber Daya Manusia, Edisi Revisi, Cetakan Keenam, Jakarta : Bumi Aksara.

I Ketut Andy Hermawan dan I Gede Riana (2012), Analisis Faktor-Faktor Yang Menentukan Loyalitas Karyawan Pada Inti Buana Permai Denpasar Bali, Skripsi, Fakultas Ekonomi Universitas Udayana Bali Indonesia.

Januarti, Indira dan Bunyaanudin, Ashari, 2006. Pengaruh Loyalitas Karyawan dan Keterlibatan Kerja Terhadap hubungan antara Etika Kerja Islam Dengan Sikap Terhadap Perubahan Organisasi, Fakultas Ekonomi Universitas Diponegoro Semarang, E-mail: indira_ppa@yahoo.com.

Mathis, Robert L dan Jackson John H. 2002. Manajemen Sumber Daya Manusia. Buku 2, Terjemahan: Sadeli dan Prawira Hie, Jakarta: Salemba Empat.

Pramesti, Y.I. 2009. Faktor-faktor yang mempengarui Loyalitas Karyawan Pada Unilever Indonesia. Skripsi: Universitas Indonesia.

Rukmi Martiwi, Triyono dan Ahmad Mardalis, 2012, Faktor-Faktor Penentu Yang Mempengaruhi Loyalitas Kerja Karyawan, Program Pascasarjana Magister 
Manajemen Universitas Muhamadiyah Surakarta, Daya Saing Jurnal Ekonomi Manajemen Suatu daya Vol. 13 N0.1 Juni 2012.

Santono, Singgih dan Tjiptono, Fandy, 2001. Riset Pemasaran: Konsep dan Aplikasi dengan SPSS, Edisi Pertama, Jakarta: Alex Media Komputindo.

Setiawati, Devi dan Zulkaida, Anita, 2007. Perbedaan Loyalitas Kerja Berdasarkan Orientasi Peran Gender Pada Karyawan di Bidang Non Tradisional, Jurnal: Proccesing PESAT, Vol. 2. ISSN 1858-2559.

Sopiah, 2008. Perilaku Organisasional, Edisi Pertama, Yogyakarta: Andi.

Spector, Paul E. 2000. Industrial and Organizational Psychology: Research and Practice, Second Edition, New York: Jhon Wiley and Sons Inc.

Sugiyono, 2005. Metode Penelitian Administrasi, Cetakan Keenam, Bandung: Alfabeta

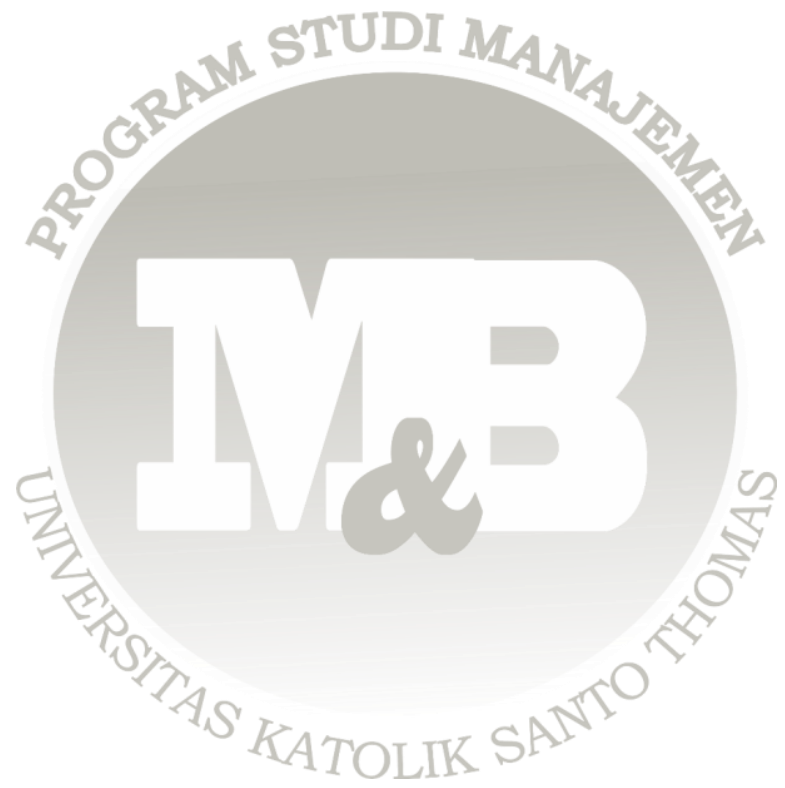

